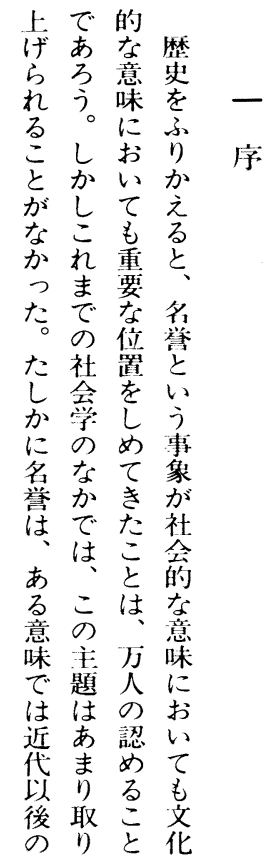

い機し題ン 社

判は多にシ会

断な学か十お

でにとんフい

まか、古防て

いをに社な退

。振公会概

ま等学念途

て返さ的でに

完け多績り、観

全れ誉少す念

なばが少での

る゙近か帒つ過と

ゼにて童去つ

ルお担符ので

シ心つ付閶あ

フこいる題る。

卜のた理と名

と価社由心誉

い値会でうは

うを的あ意き

理無意乃識わ

念視味う。か

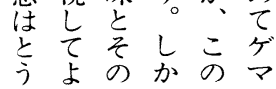

置克し場し主題社な成か

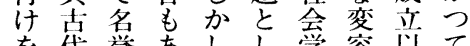
行帒誉あれ、し学容以て うら権ば名と論経に $\mathrm{P}$

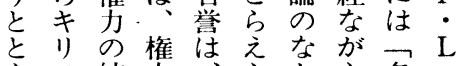
毛統妿方尔名: に上合と権れでも誉心 名思態あにき誉価はガ 誉想がいよたは值価、 のをどな゙う。稙は 変経のにてそ行重の近 容由よ葛つの為要中代 のしう藤くい論な枢意 理、にやりずや立で識 論近関摩出れ集翼あ成 的代少擦さ甩団をり、立 な初るをれ、論担、の 契期か起る権につ最結 機にに毟も方括て重果 ななつ場と形てるな名 んるて、合い態はこ社誉 で寻社毛側従社々会観 つ口会る面属統か成念 たッは自方合わ原衰 か思棝名みる価学でで退 か思性誉で価側はでし 論の具特む解とからいたい

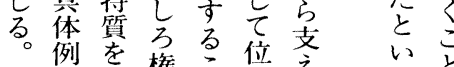

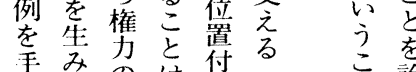
が出形でけ付要亮論 かす態ぎれ要を゙だ

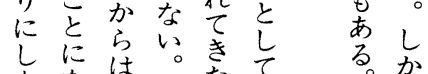
なな独名た論方充

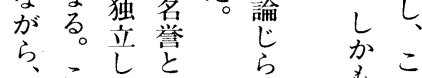

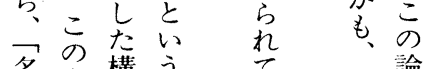
名誉占成価息名文 な原值誉の中 と視理は咅

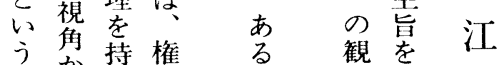
価か持権学観を正

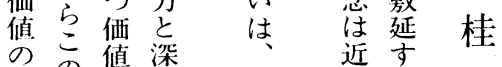
社の值染近染

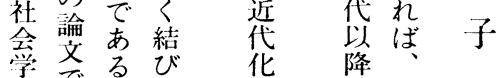
学でる。゙ 化 降

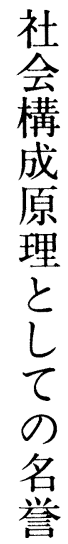


的の会近思合いよ付志り值とる なま構テかの

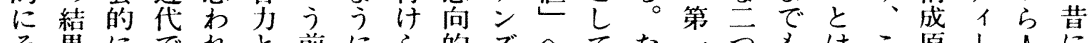
そ果にでれと前にら的更へてた二うもはこ原人人に ので認はるし提のの論とはの当いれ理が々破 存あ知名。ては議て為かコじ之、ア然之をの社がら

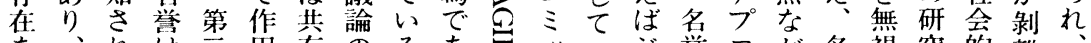

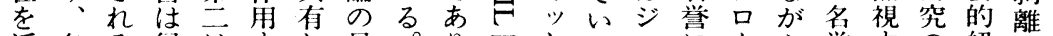

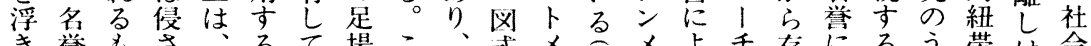

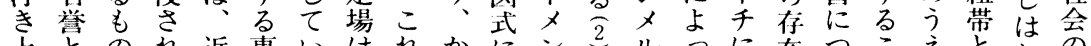
上とのれ近事いはれかにンじルつに在つこえとじの

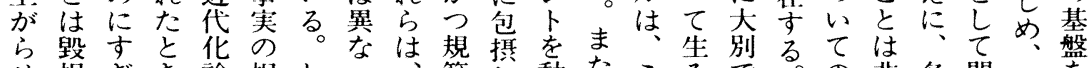
せ損ぎき論根しつ、範し動たこみでる。の非名問あを る索なにの拠かて二文て機作れ出きこ重常学題ら理

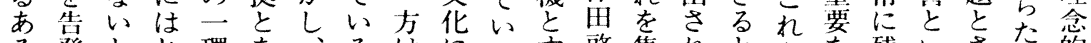
る発とじ環を、るはにる市啓集れとらな残いさ学

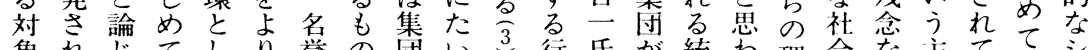

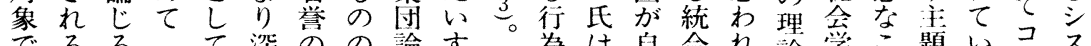

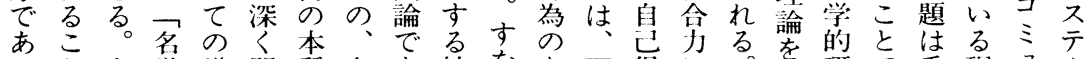

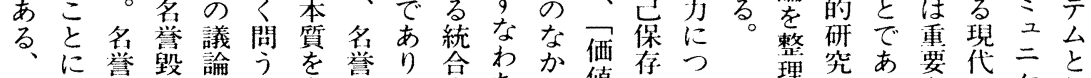

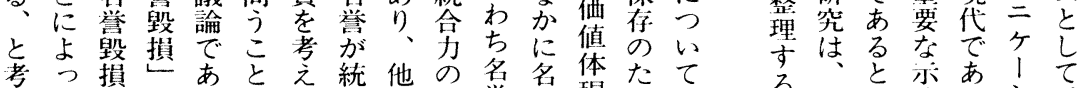

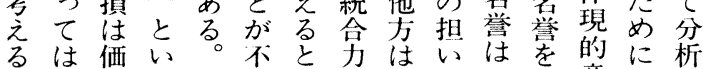
。し值うこ可きと行手一分意働し ジあ統かの众、し為と貫類味かた ンて、合た議で曻て論しししをせも

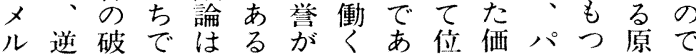
は説壊社祬とる置值、価理あ

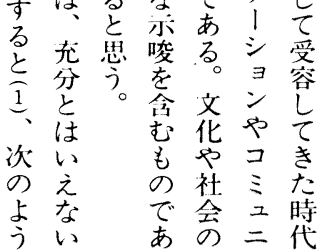

性るるれはる場変価てての を時。ら方ばは数值、選だそ 架代こが互し、でと支んとの むもの歴いうこあ人配だいう とあ三吏にるのる々の価う之 いるうの独こ後との正值立こ うがの実立とにい持当場れ

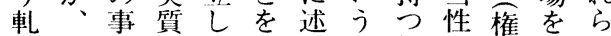
轁逆象のた説べ価や方との のにはう事明ると值安のう名

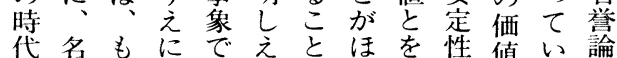
も誉ち興あなにと統を基るは

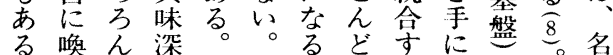
る。喚朵深独むるる゙する 独さ百. 個立しう議毛れ支権か 立れに性しろ、に論の支力権 しる結的た名尔でき配は妿

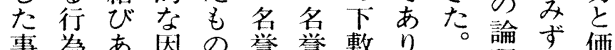
事為あ因の誉誉謷り、名理か価 で支強連あい権にこ誉にらと あ配化関るう务あのは取のの るのしをが観のる意、り正結 が論あ織ゆ念存味権込当合 ゆ理うり之立しで力む性関 えを関だに支をか支のこの係 に覆係守こ配とし配作と根を こ尓をのそのきこのり拠映 そ危う、で、論にの従出よとすす 險くあを理摇立属古うしも
る。近、会面导題 $\mathrm{P}$ れ 名 代牙专学、東心け誉 基槀物使近文文がば法

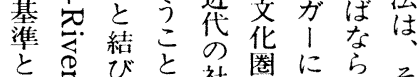
と怘びと社圈にらなそ

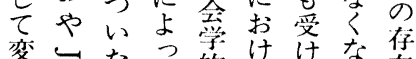
栾—たて的け継っ在 を○名名样る継さ根 見凹学誉組面れ拠

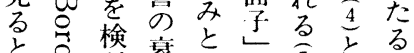

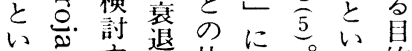
う方非方最方的 限論るた較い最。の 界文と姿検て近こた ま学う浮を愍よに ぬに研奨たに方は がも究彫て焉学な近刑 てら礼它代法 いれ四し関批に なる。た近論わ判よ いが氏り代文りはつ よいだ、とにに他い深の補 でずでのういいち足 あれな社文て 主にさ 


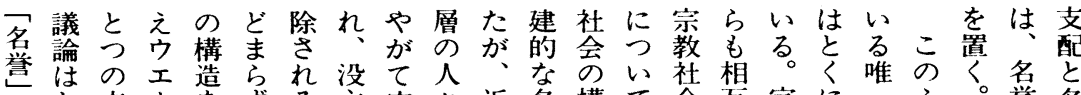

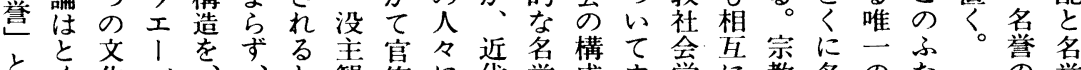

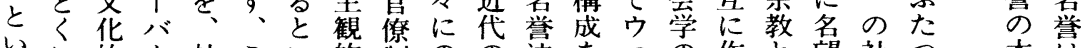
うに的! 社こい的制のの法をエの作と望社つ本は

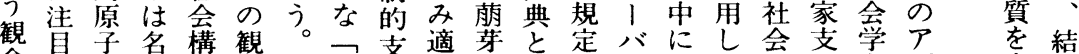

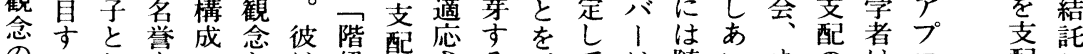

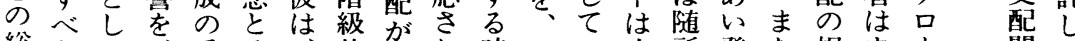
総きて、重々桨徹れ時㭚い次所発た根门! 関た 体で名権要の名況底名代権たのに達そ幹エチ係り

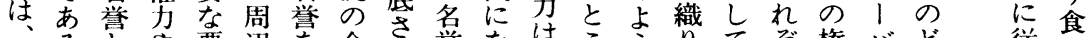

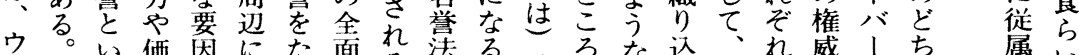
エしう值の噴ん的る典と政で歴ま社にをでら等をであ

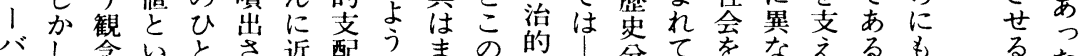

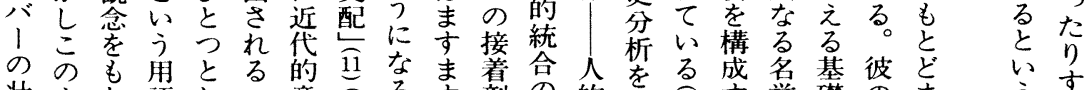

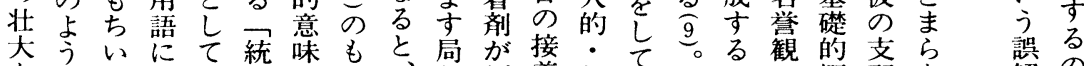

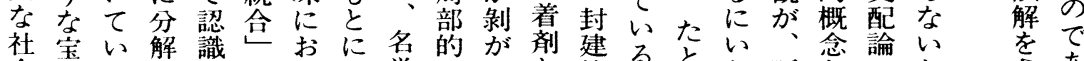

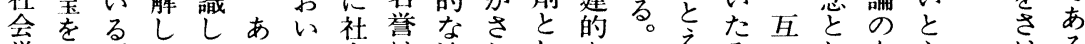

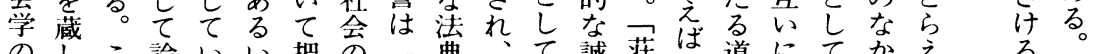

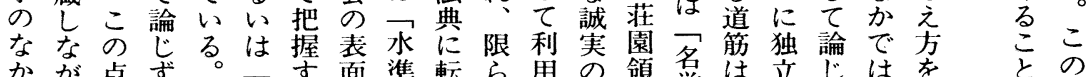

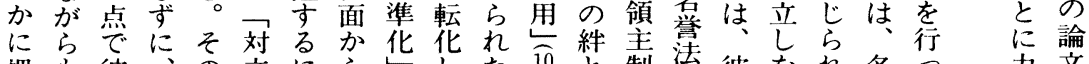

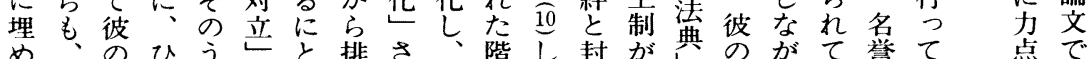

もける䦙向之さ治原り込則リ

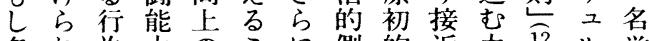
名れ為力のこに側的近力西儿誉 誉るととたと権面共香のにもの にもは寻めは务を同る担よ言原 反のに㣗切体こい?う型

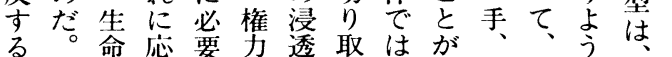
こ名へ伛の学つ名デ生に集 を誉の配集統基はてこ盤かュ物誉合 彼る虑夺技とるる融るケ事初体 が人をに術な手な和行㕕物的 行間無対のる段ら力為なも共の つの視す根べで名がでら、同信 たもしる幹きも誉政あ集あ体仰 時とて義幹武あは治つ合るでで はに闕務あ力る。的た表融はあ 集方を方集機と象和はあ 生まこ誓たす戦団能言との融た 命ると葯夻な果の柱をい状即と

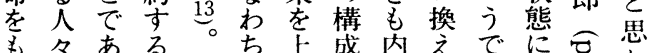

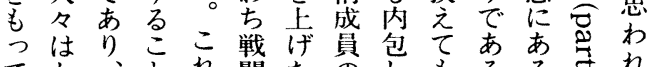

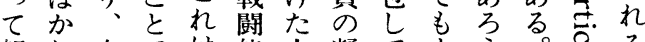
報れ血では能人凝てょう。总る。 復ににある命よ間集いいるが融怘レ れをつ高質名をかまこへさきヴ る預て名さの誉高らたれと代

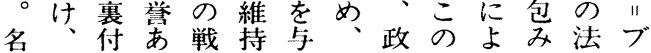

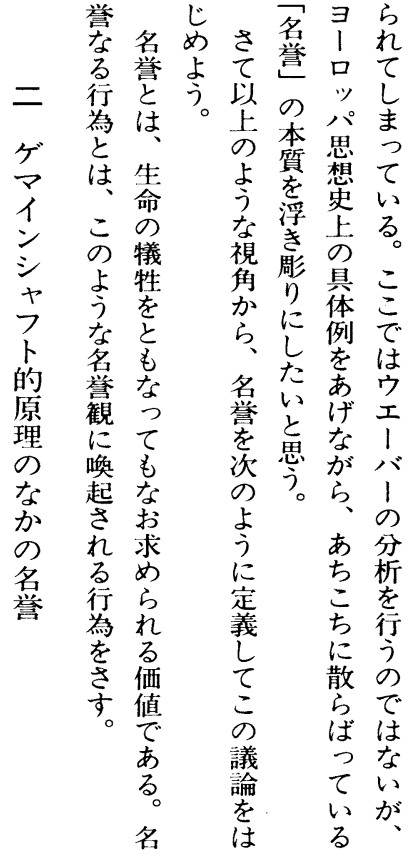

$42(3 \cdot 68) 280$ 


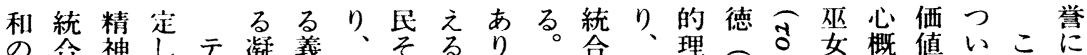

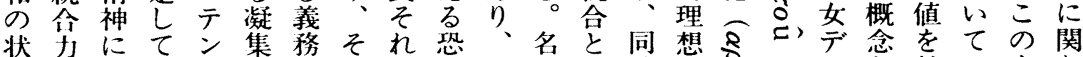

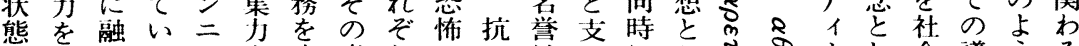

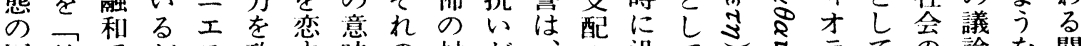
国德てがス政索味の対が、の汎てさらテて、論な関 芜迌しは治るで心象たポ正神のへ杏人、主を原係 にでいこゲ権こののでいリ当論イのきる知軸は初は おあるこマ少と社高あ恍不性的デ恋化すにじ的

ける。でイとで会揚る惚全が宇アは多な置め意生 るとモはンしあ構がこ皆体獲宙へ昆誉わいて味命 德いシ人シてる成国とあの得への常さ心ちた行をを

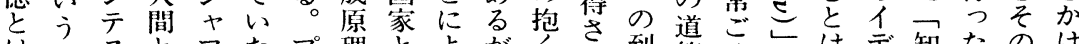
はがスとフたプ理とよがく市到筋く志はデ知なのけ

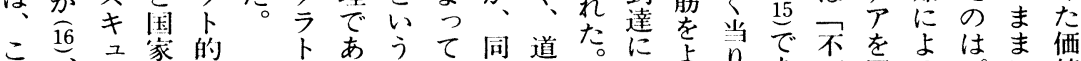

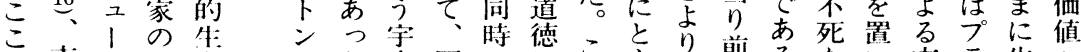

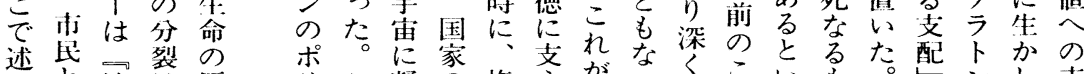

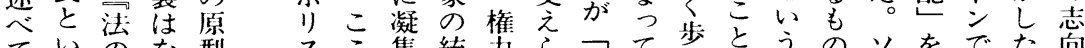
ていのな型不こ集統吕ら哲得省でうのりをでた向

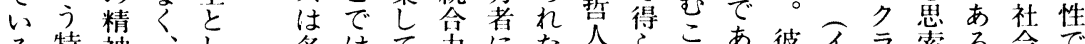

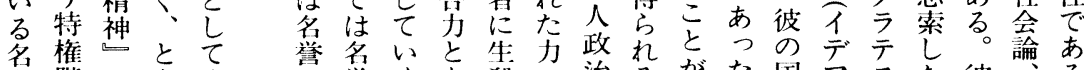

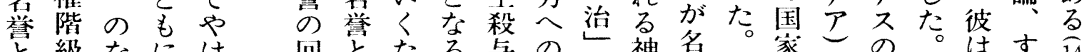

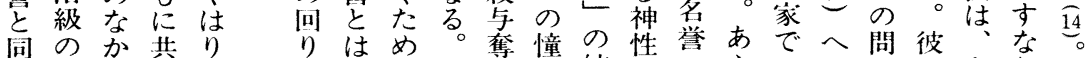
じつで通ポに集のす集愫に統にらはのいは名わ 機くポのり分団触な力の合よのゆ恋に社誉ち 能るり感不泌に媒わをこ力つ道る普ご対会と名

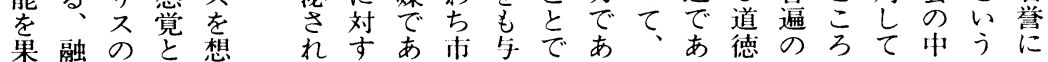

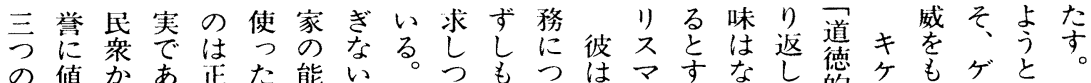

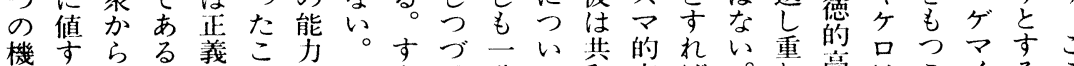

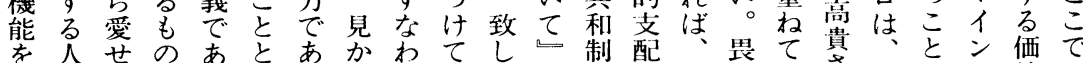

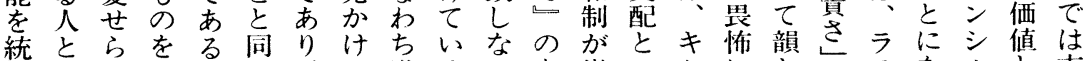

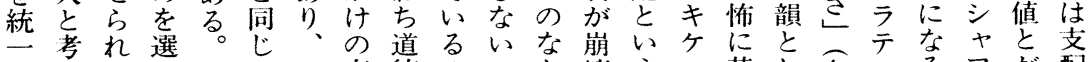
的之るび法でこ有德のこ尔壊之基し名ンる。フが配 にらとと法あれ利的でとでしるの年て詞語。卜末栍

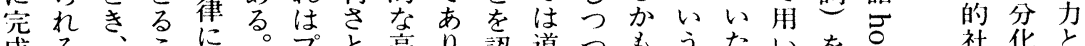

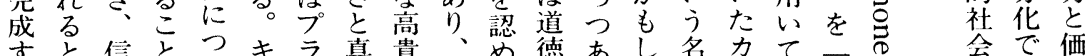

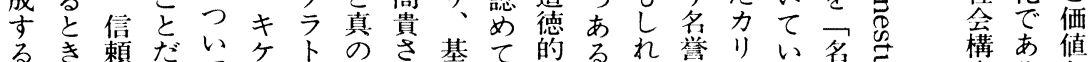
の、せとてロン有と本い高時な孛不る䇾声成りと

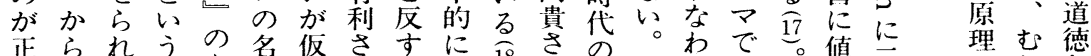
正らな義なる

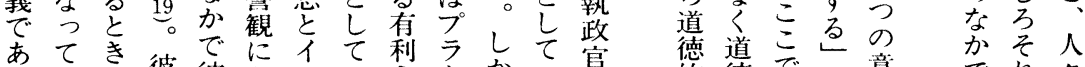

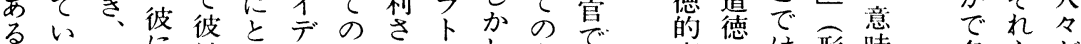
。る賛にはっア徳とシし名あ高には形味名らが

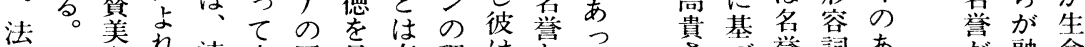
律そをれ法中区貝有理は它な基学詞ああが融命

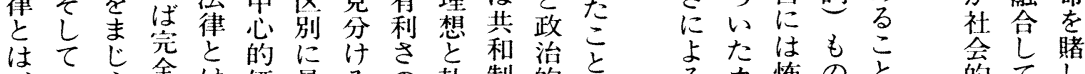

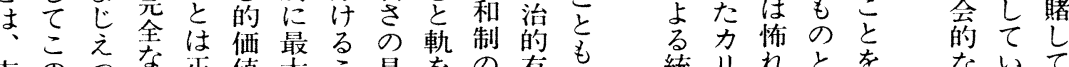

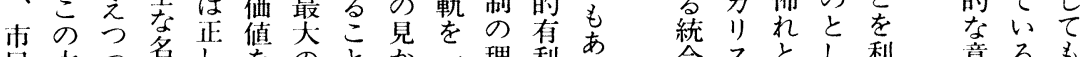
民本つ名しをのと举立理利 り 合スとし利意るも

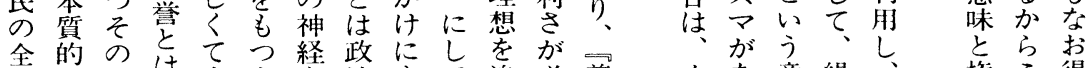

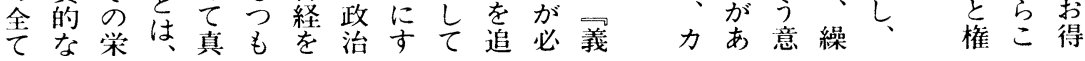




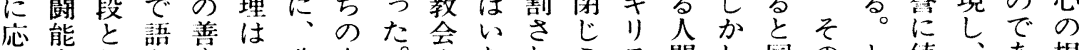
し力乞 吕守 $\widehat{20}$ 政士。令たれこス間し同のと值、あ根

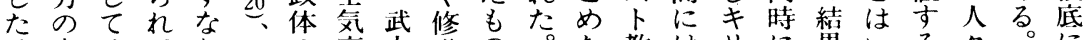
政高々てわ备の高力道の教は师果いる。々。に

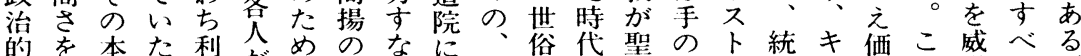

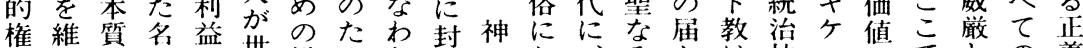

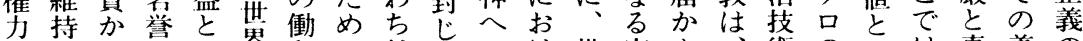

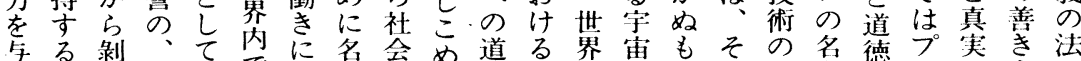

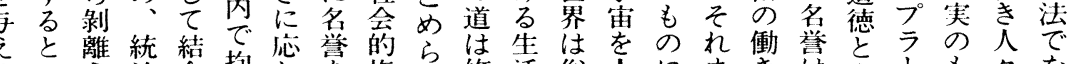
るいさ治合抱心究権れ修活俗人にまきは人卜も々な

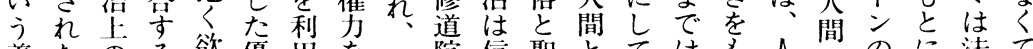

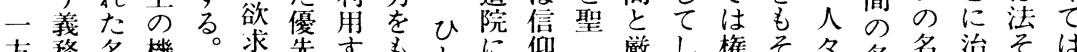

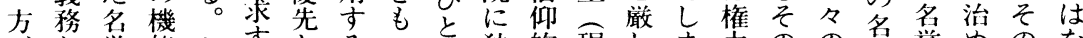

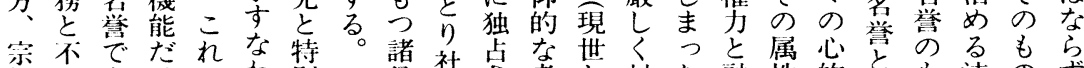

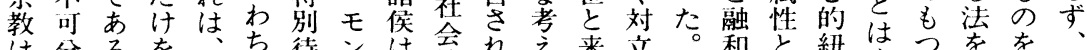

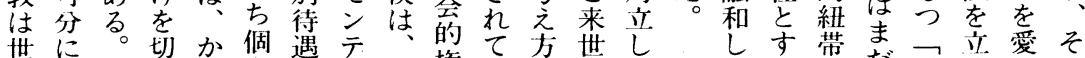

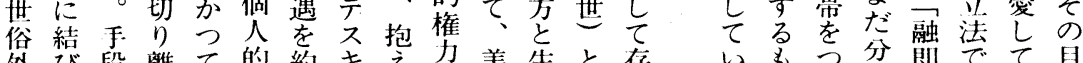
外び段離て的約キ方美生と存いも分即でて $へ つ と し$ 共利束之てだや活い在たのく化尔い標 ときした和益夺、いけ辡様う专德にりしがるる。は 志さて、制をるがるが智式三るるをなる崩人。善 少義のいの政名指多世とにう神主うげは塤間徳の す務名わ理体誉摘々俗い満の格現てるいしこと究 るの誉ば念にと古のにうた世年世源な始そ知極

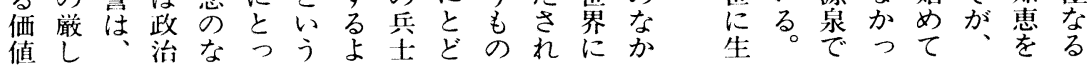

らはてさるでば亀ば権誉しと無名なし行形力の

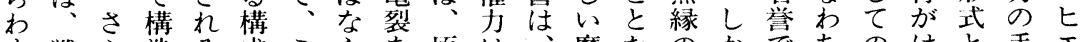

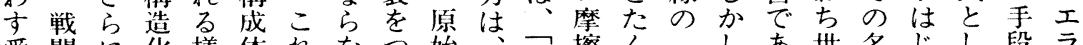
愛䦙に化様体れなう始、支擦んへしあ世名じし段ラ の能当子でがかね的そ支をに力ウり、俗誉まてとル

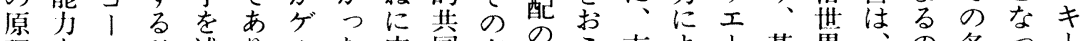

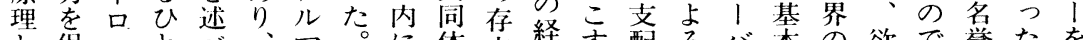

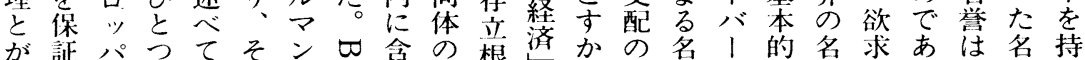

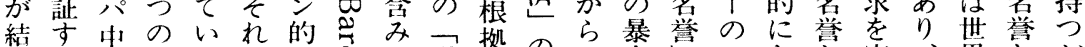

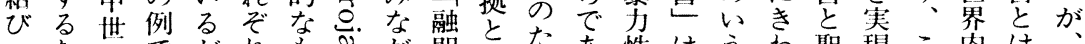
ったにでがれも㐫が即したあ性はうわ聖現こ内は

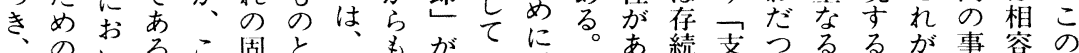

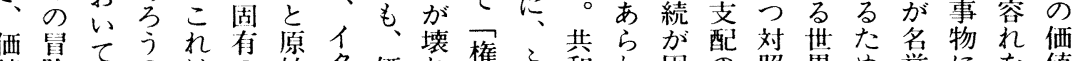
值険重 22 はの始多価れ権了和わ困の照界め誉にな值 とと重。相文的少值た力た制に難経をのにの対いに 権、要窝华なアとの価び理なで済な名必たす独基 力キ例れの近のち、值便理り市守誉要める自づ のリな個の世論、值便念、る。基。はなの欲のく

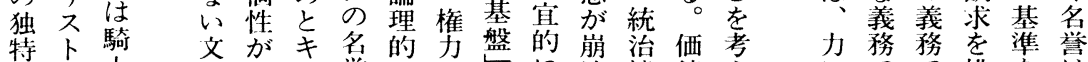
の教士: 化、リ誉なは壊機值之 結の的的場 スに結そを結し能のる 合僕离要合卜つ命の求びたと観と

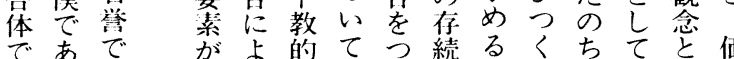
あるあ権つな論く尔。。分はの值 $つ$ る。方てもしらた換す裂い縁の

たと。に浮のるなめ言なしち無観

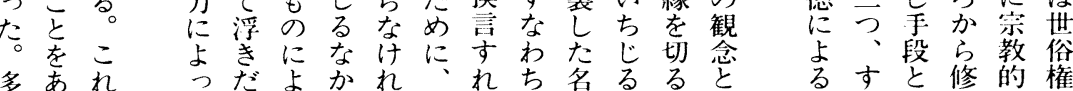




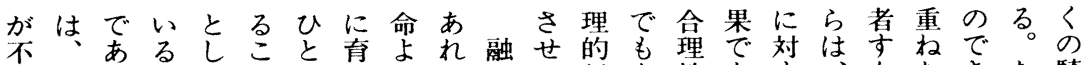

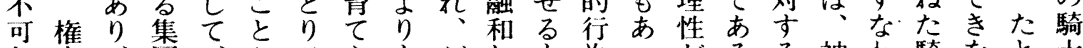
久妿、団、がしらもゲしも為つがるる神わ騎なと士 でのすの道、とれ重マたのとた融。忠でち十い之物 あ価ばな徳ゲりるいイ全に徳が合プ誠も円道不ば語 つ值らか的マが毛人シ体転へ、しラとな卓の思、の た基しで価イ持の格シと化の騎た卜弱くの習議円中 社盤いは值ンつで的七しし価士行シ费騎慣な卓に

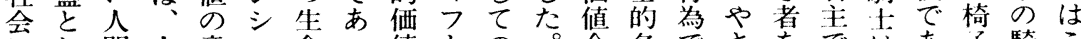
にし間人意ヤ命つ値トの。畣名でキ学では市子騎こ

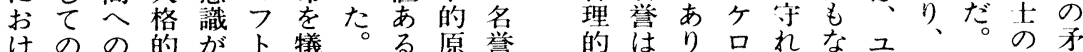
る 人従働的牲支い理官行、にと多キこ席盾

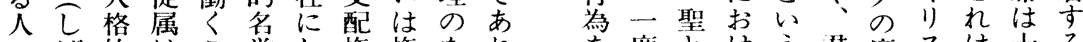
夕は的はこ誉し権権なれを度とけう君席スは士る のし従人と全て力威か、俗るキ主を市言も 統ば属間があものとで㫣亀離名りの空とりあの 合宗はの不るな正し社裂裂反現誉ス费席辟スるの

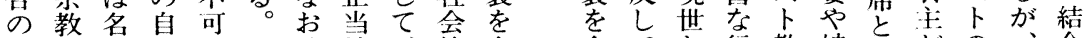
象の誉発欠つ欲性、的含含てと行教娘しがの、合

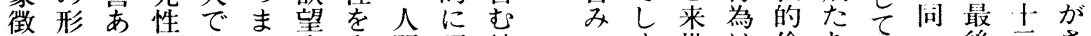

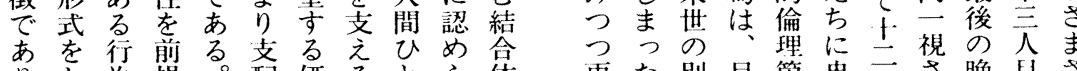
りと為提。配価るとら体再た別目筒忠示さ晚目ざ 、るでに名関值社りれと権を的条誠でれ餐のま

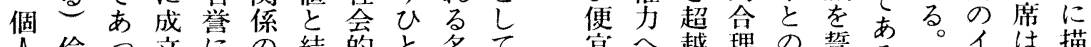
人倫つ立にの結的と名て 宜へ越理の誓ある。イは描

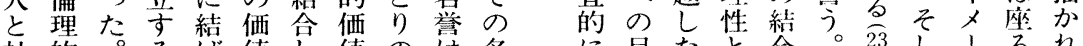

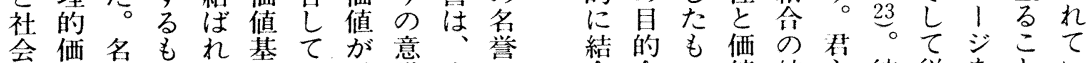

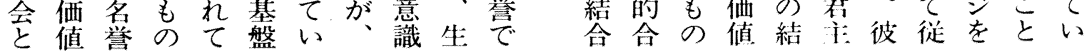

調とで徳いた第れ位出方人観重らる

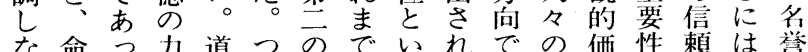

いをたに徳ま方論う得あ上值とを元

。犠。溢にり法じ客なるに至爑通様

し牲もれ襄、艺て観い。輝と上得り態 かにしたづ徳はき的よすく変権し、の

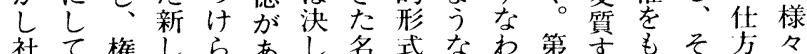
会ま妿いれつて誉を社ち云るつれがな 会でが支たて名は通会地は場ゆあヴ 組た道配力こ誉第艺的位、合之る。 織か徳者川そは高て凝に同のでに第尘

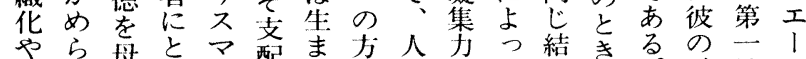

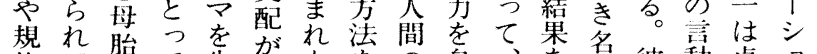
格て琞て失特なをの身、学彼動卓妇

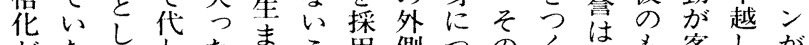

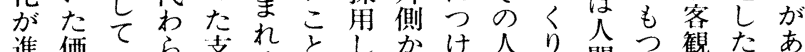

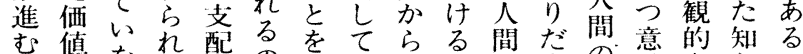
に值なれ配るをるてらる間な゙意的知る と欲こと息でこ成着合内に部し側法方し

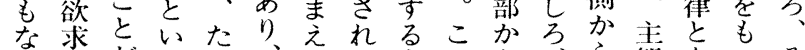

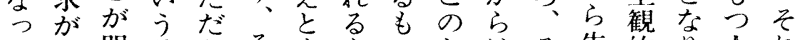

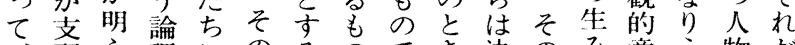
、配ら理にのるのでき決のみ意う物が 身愿かが生逆もであ名し方出見るが構 分理に不きでのある誉て法さかほ人成 とにな听たはだり。珄はれらど々さ

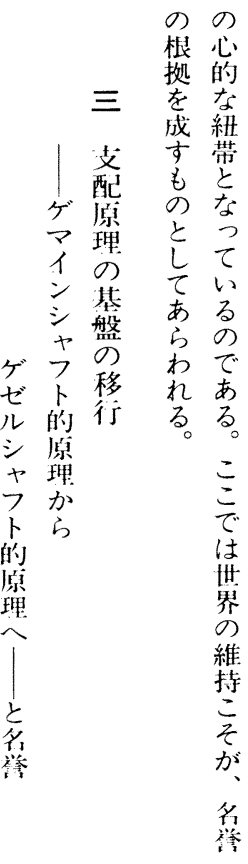




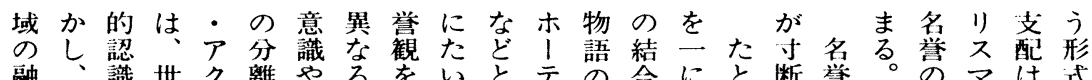

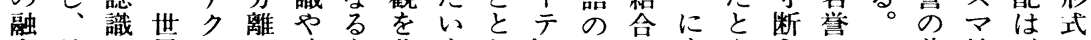
合結へ界イは時も共すし学なのすえさの前性、に

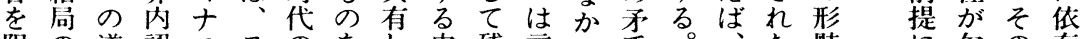
阻の道認ススのをし皮残言に盾。た众の存 みとっ識のコ境みな肉さうさが教騎と化 あ落権玄

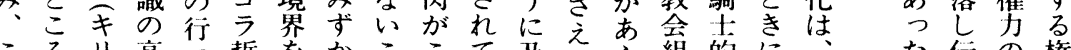

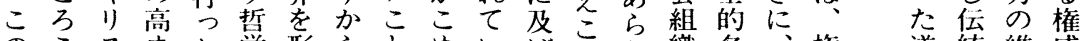
のこスまた学形らとめいばのわ織名、権道統維威

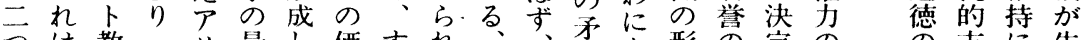
つは教○り最し価すれ、矛な形の定の支に生

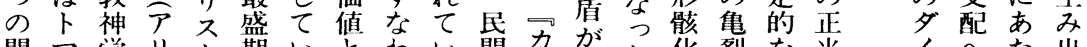

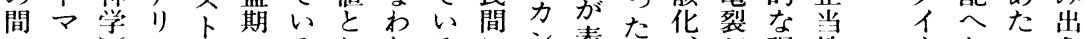
にス片にるしちちるに多表。面現性ナとうさ

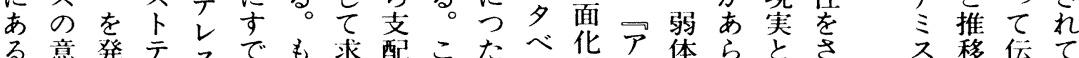
る意発テスでも求配こたべ华ア体らとさ移伝て

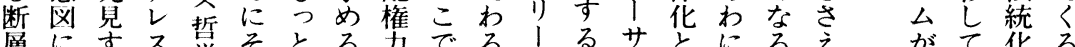

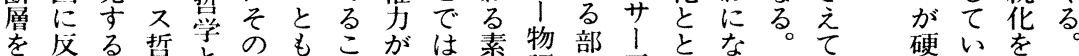

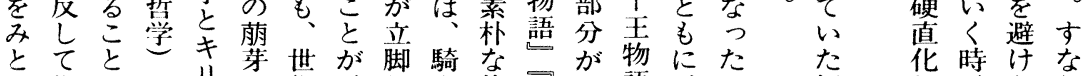

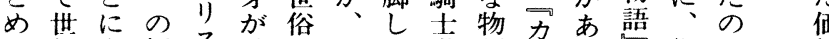
る俗よ極不見のひて道語ルるる俗は値化れち

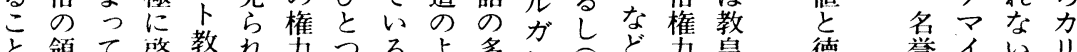

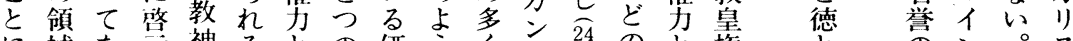

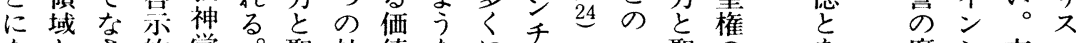

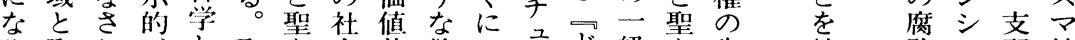
り聖れ、と聖な会基偽こワド級な失結敗十配性

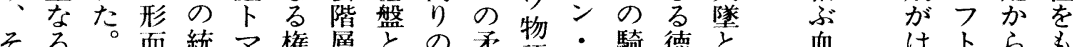

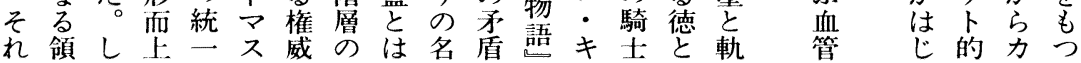

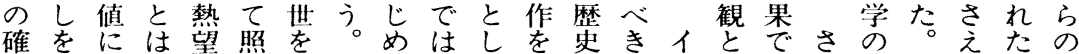
か名よ死しら超彼てなた生を価多はあて世才甩世分 な誉つをたし越の真い運み超值りこる権俗多、界離 道にて克人だし言のと命出越とアと。力的力精はを 標求現服間さたう名考のしすなななな神、準 とめ世李でれ世名誉之偶てるてルると価発にとた備 なたのるある界誉はる然も徳選ネ名え值展い感とす

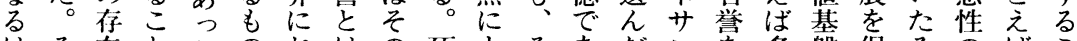
はそ在とたのおはの死よそあだンを多盤促るのばこ ずしをでがでい生人がつれつ德不求くの手と質不と のてよあ、あて存間そてがたはのめの形こ的ピに もぺりつ著る輝中のの左社。キ花たル䯓と哲分广な のト確た書。きに徳人右会ぺリ開かネ化に学離ザつ だラか。抂ぺ、徳を間さのトスくらサはなのはのた 。な現凱ト来に発のれ人ラトとこン方神否よ

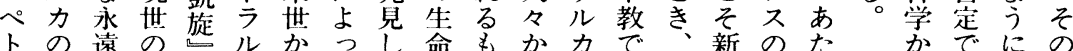

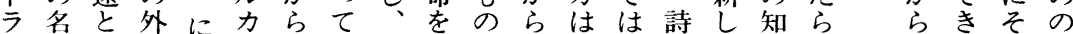
ル誉す側よ自現種名現で称な人い識しなすれれ 力はるにれ身世がを実、賛どくぺ時人い分、らに の、こあははに播輝かこ学は代た名離聖のな

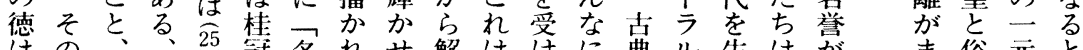
はの、等名れせ解はけに典ル生は唯ま俗元と

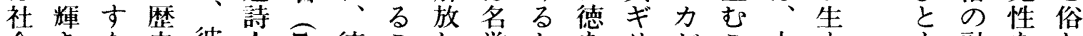

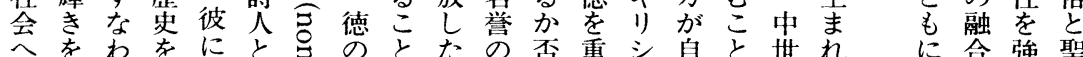
の毛ち超といた大にの真か初分に以な要は調と 献つ存越つう过なおのは哲が前こ求否しの 身て在して名しさるに判ち善学帰つのとさ定た二

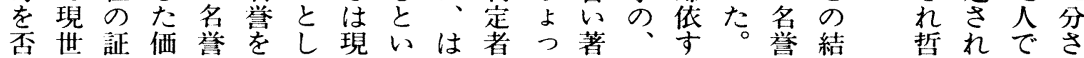




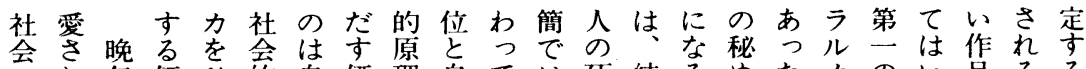
云年価ひ的自価理自ては死結るめたカのい品るる 利るの值と地明值の分い、に局とた。に倫るをこも

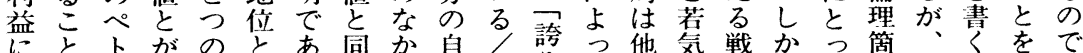

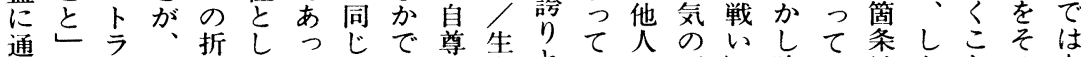

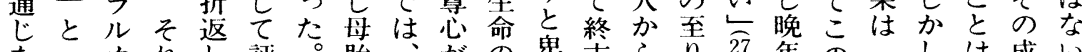

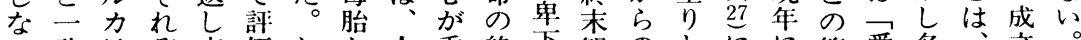
い致はぞ点価しか人重終下観のとにに筒愛名市.

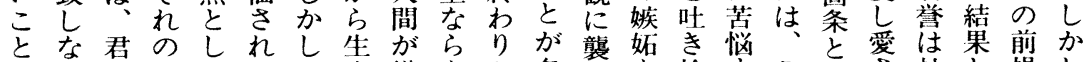
をい主独てるる゚ま犠なが名わ㐬捨夺こ名究社と提し

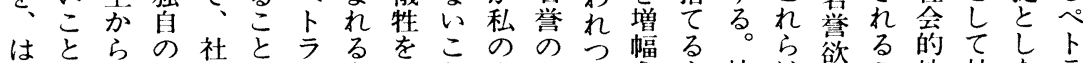

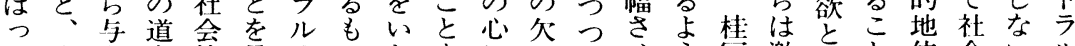
きま之的最力のとをにけ書せう冠激はと位会いル りたら步な後はでわ告のて昆たに詩し立高とに。力

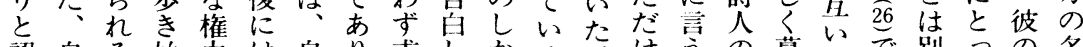
認自る始男は自り求しかるたけ方の葛にで別うの名 め分名め構諦ら、めてかるで。称藤強あのて名誉 るの誉る造めの名る心る气自あ社号等強つ独の举住

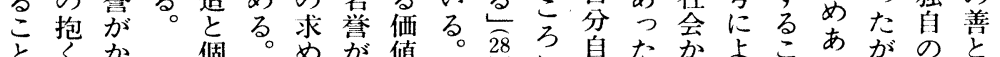
とくか個。めが值。28 に自たかよこあがのとす現 に愛な人する集はゲとに身とらせをいい、基なな世 ながらがな名団名書同へ溜与たに結青準るおの

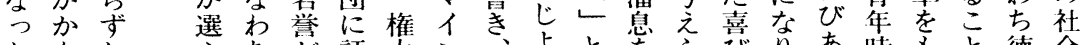

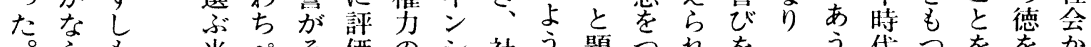

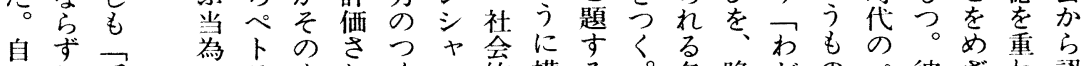

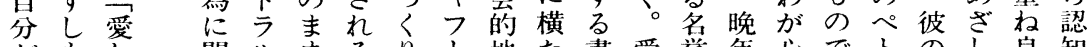
がもし関ルまるりト地た書愛誉年心でトのし良知

もがはめの切い関るも務ら命あの名り名のを值求 の、ら離工り。係時なをれのつぺ誉歴名世克基め とあ現れ反ラ乘この代う負な犠だが史のに脤盤つ

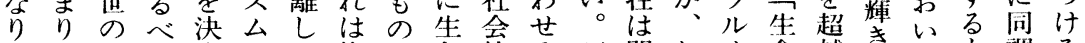
に権き定不た権でき的るゲ閶し力命越きても調る

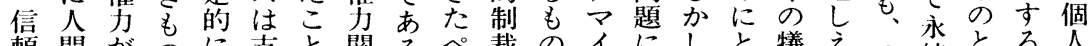
頼間がのに支と関るへ裁のイにしと犠えそ続とる人

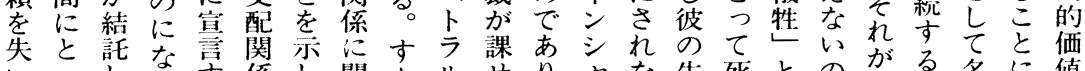
いつしつ古係し関なルせりなな生死との社る名に值

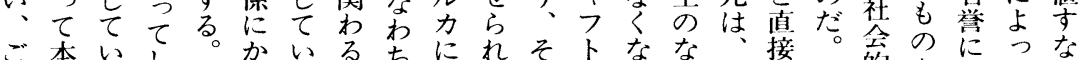

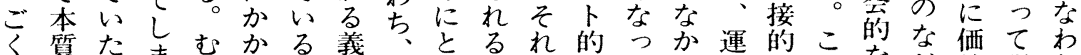
限的価ましわわ務名う气名たで命でのなど值得ち らで值たろる誉ての意誉。はの必た道なをら自

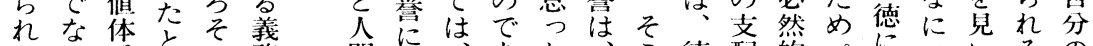
たい系々の務間反汉あた氙徳配的ぺにひいるの 宗束○市名つ場名にをなかな﨎ととだ社名

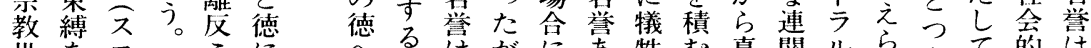

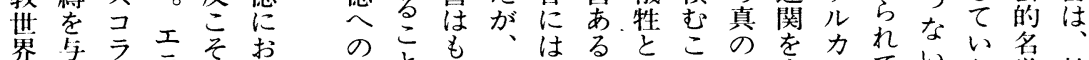

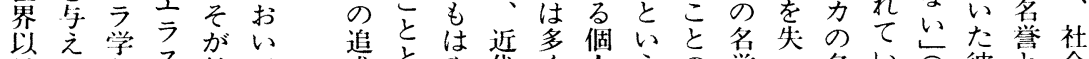

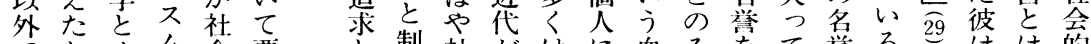

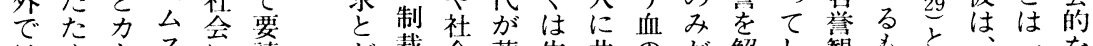
はめトスに請尔裁会萠生共のが解し観もと文一な

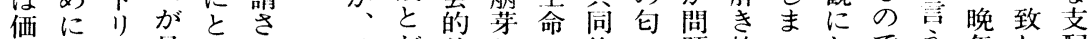

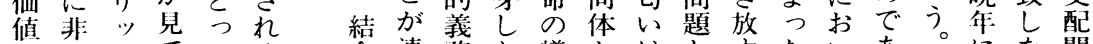

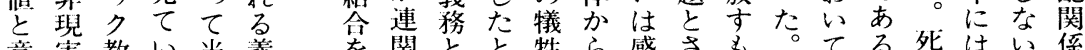
意実教い当義を関とと牲ら感さも在とる死はい係

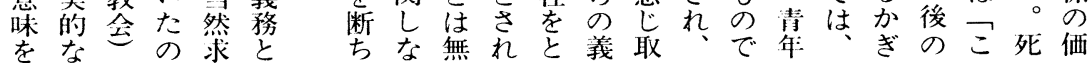


件っよは性ないな情に科涉をなり人ラ理るてれど失

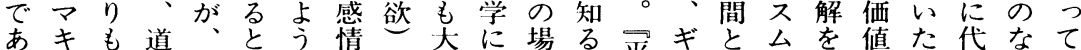

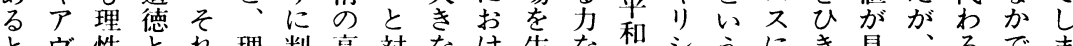
とヴ性とれ理判高対なけ生な和言うにき見、るでま いエのい自性断揚比影るみの朶類とだい君新りつ

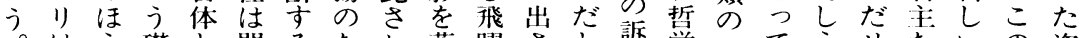
。はう礎と閣るたれ落躍さと訴学のてうせたいの姿 君、がのし題ためてと的な述之と尊理るなち道価で

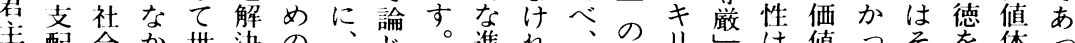

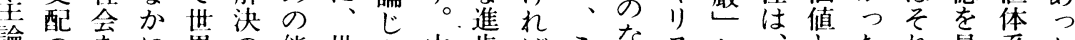

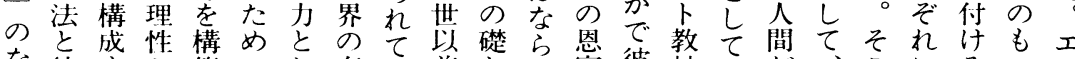
な徳夺が築のし存き前とな龍彼神あだ、こにるうう かとる包夺能て市たの市溢は学らけ新で異こ空

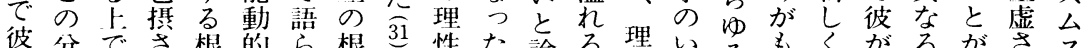
彼分でさ根的ら根 310 性た論る理いるももくがるがさ は離礎れ拠なれ拠すは梨愲方性ずるうう提さ価でをは

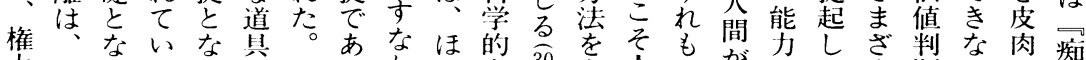

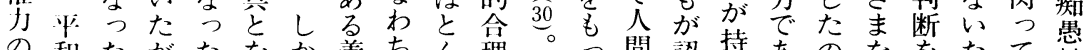

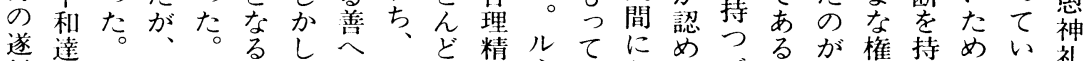

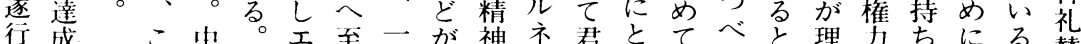
をのの壮善ラる時感はサ主ういきい性のち、にる。替

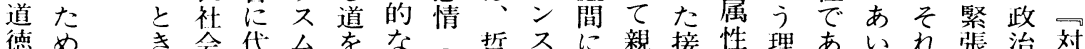

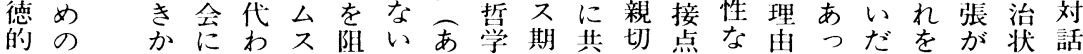

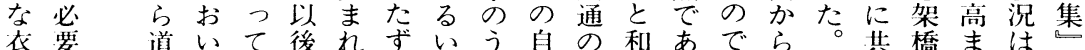
に条德て理にならは之然交合っああり土通高うこな

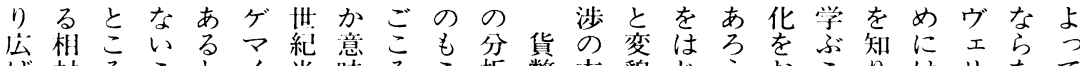

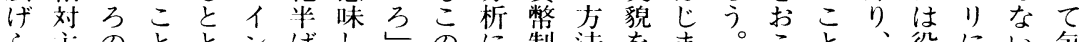
らさのととンばしてのに制法をま。こと、役にい包 れ義、にもシのなの時あ度にとりマながし立とと立

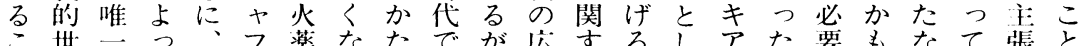

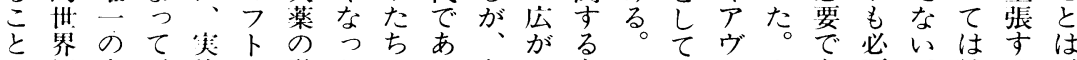
に観文、靴的発たでる。主りもこ、兄要。戦る なは化裏的多明時あ。従がのの法リ工るに君争。政

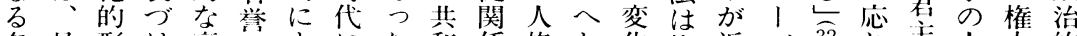
名具形け旁のよにた和係格と化権近バ

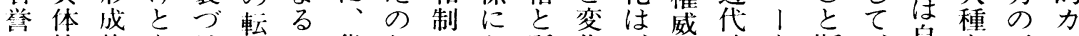
に的物なけ覆つ新だのか所华政な断、自を正モ

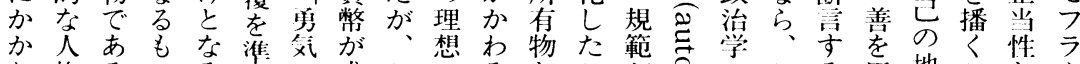
わ格るのる備の求このるとこが马.のこる。解地こと!

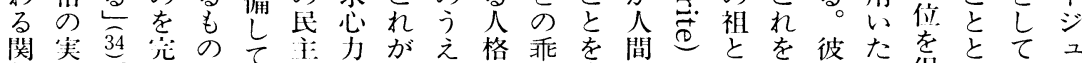

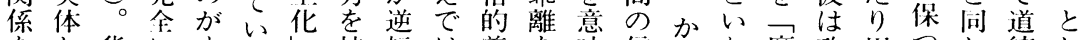

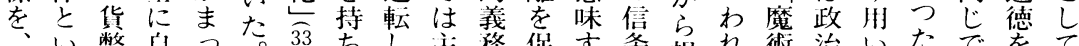

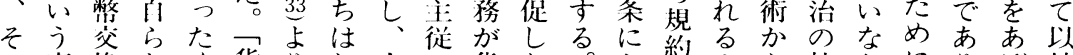

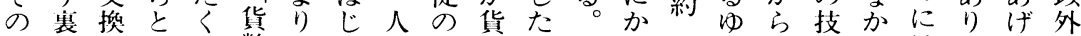
传づにりた幣もめ格人憋こ汃えの術つは、、る

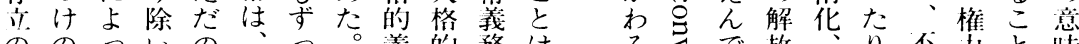

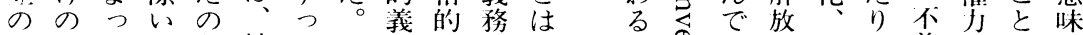

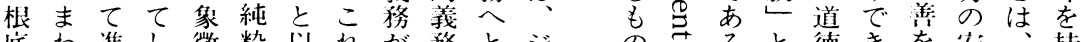

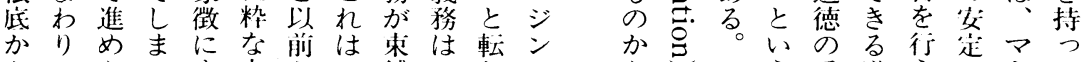

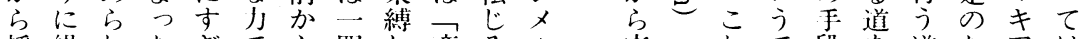

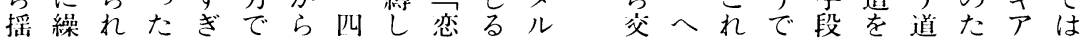




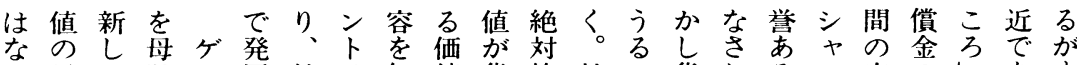
り母い胎マ展社ラ無值货的社こ貨れるフ客のしあす 得胎道とイ壬会ス視は幣価会と幣る人卜観制つつこ なに具しンる関トし関值哃をの。関的的度またと いはでたシこ係をて貨係の係前原すを原価化りのに 。なあがヤとを毛成幣に地の提理な尺理值はあにな しらり、フに支っ立関飲平あとは方度のは人效る。

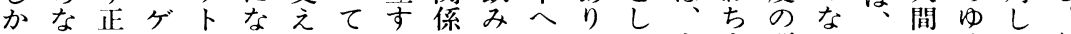
しい当ゼ的るるとるの込とかて人頂か货のるるな 性ル原。位も価相ま—た书間点で幣価相貨と 人すそ三理置に值対れ二とりののとは管值对幣之

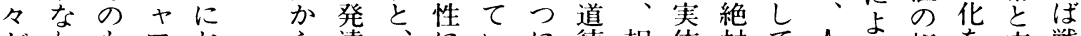
がわもつおお達问にい德相体奶て人相を交戦 自ちのトい退し内たく寸的对は的、間て对拒換闘 理に的て かは容いこ断価的貨価最の集否娄の

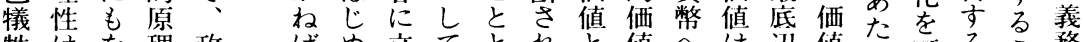
牲はな理政ばめ立てとれと值へは迅值云叮るこ務

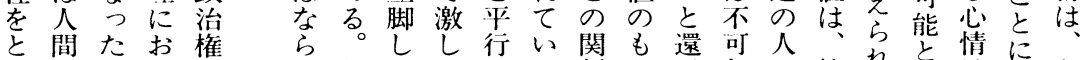
と間たお橅 もが理い力 なも 性ての て ぬは、 政值 毛文治基 な価れ的盤 お值自境は 求之体界 めのとを現 てもし超世 やのて $え の$

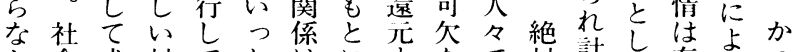
か会成対て、ははに李なで対計た存るつ つ統立照、势社さ的量在車て

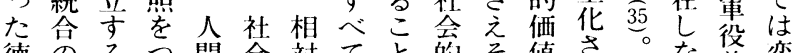

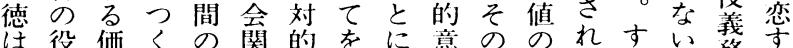
割值る救係価取上味尺あるく。技る

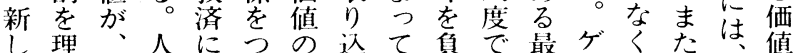
心性強間かく地ん無方判高マと殺、へ 地にいのかる平で視。断のイも人急の まに価る善平譲コ内価といししが名ン人賠ご接

存が成人思ら神か自いい被がリめつ裏め決俗ちな 存立間想こ的ら由るか造いスル陪とづにしのつい 在く李にはそなこに他な物たト不落しけ特て価救価 そこる生中凡存う選の市で。教开してら永做済值

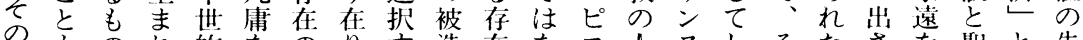

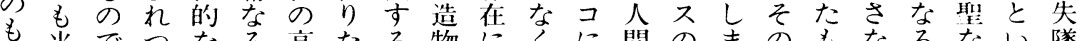
の当でつなる高たる物にくに間のまのもなるない墜 の然あき世もみいことも、像知つ行のけもるうは にのつ上界のへととはなむれを識た為でれの価新 価こた位観でと欲が異るしば提人道をはばに做たキ 做としのをな至すでなころ人起た徳制なな直がなリ をで、も覆くるるきり方不間しち御くら結珙絶 㤎あ下の想至こ毛る、が定とたのキすななな質対卜 めつ位とも高との脰のは人共りるりかなな的教

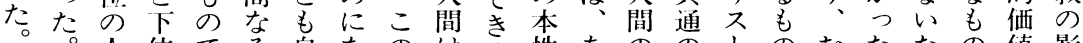
こ人位でる自なのはる性あの市のむたたの嗔影 こし間のあもらるよ自 尚をらひ論教とし観めでを響

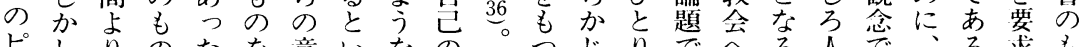
ピしりのたを意いなのなる゙りでへる人で、求も コヒもと求志う不意あ動めにあの。間あ特た守上

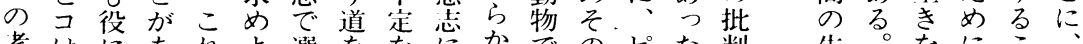

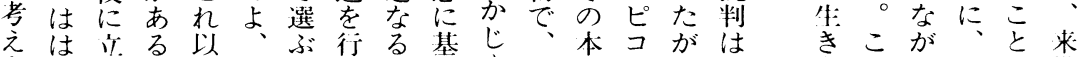
え

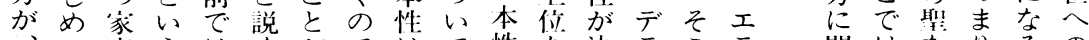
て、音うはく。がでは古性あ決ラこラ関はなりるの

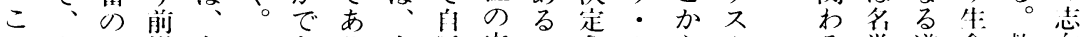
の人ほ提身こきり人走いさミらム管道命救问 す間うに分のる、間のめは防新不德は老の済性

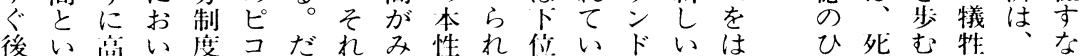

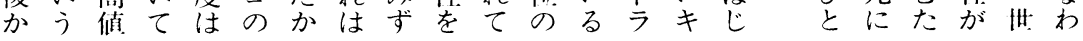




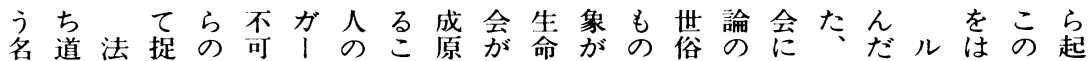

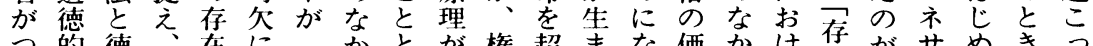

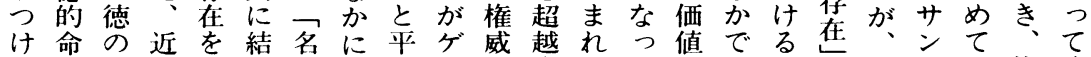

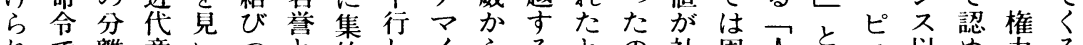
れで離意いつと約しイらると社周人とる以め力る たはに識だいいさてン規価述で会知格てが降るの宗 あよの市たうれ約值㢳市的で的て発のこ支教 人るっ発人存概て人十をもてるなあなの発人と配改

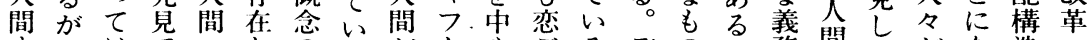
ず社はでへとのくがト心ごるデのが務間だがな造へ

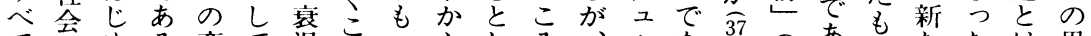

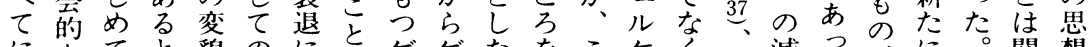
になて、と貌のにとゲゲたをこケくこ減っの、に関想

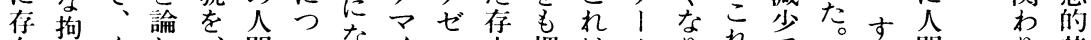

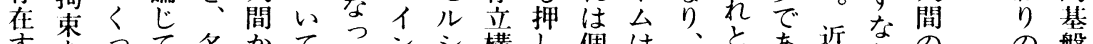

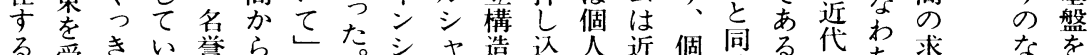
る受きい誉らしたシャ造込人近個同る代わ求なを 尊けりたか、とっい準

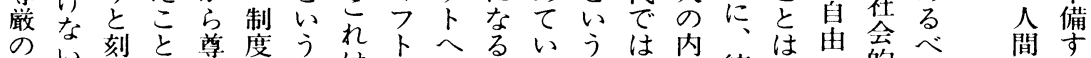

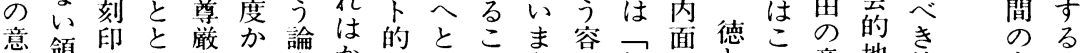
識域さ同へら文か精々と㗊個のと面意地徳存气

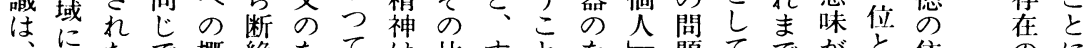

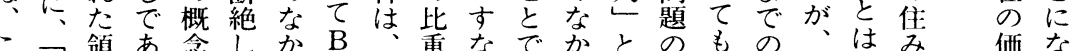

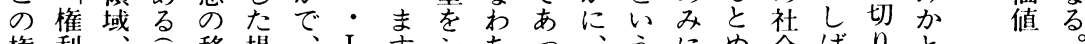

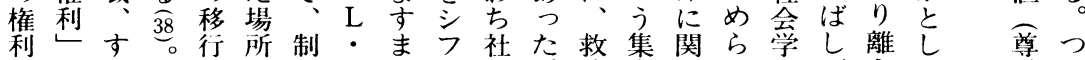

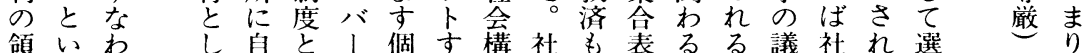

社がは対な会啓 会あプすルう菂蒙ル がるラるソたな主ネ あな卜愛! 名義 サ

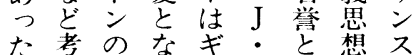
。守る リ J は惢以 ルら雸よシ・相萠後 ソれのう十ル容牙の

人な完な哲りれを哲

はい結政学、な生学 さほ性治をはいみや れどは形学、個だ科 ら不も態びこ人し学 を平は童うと憧うは 融等や模れ 合な跡索自世社型のい 上会なるら界名近人 人 人崩し、电它哲の 告間れ自し心学道 る。善人し、导で観は德 $\neg$ 間儿対あ念支培 自道にソすつを配う

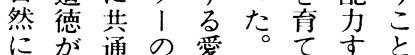
帰乘目がるなに れ離たの国土わな とた価前家壤ちり 、
白な構いりてが厳与主域 名分つ造。うは、は義に 誉にたと価るなこ価のの用 四㤎課。し值毛行問基い ゲゲ倫ト存ので問人係は題礎こ ゼゼ理ラ在市わ間に心価れ、

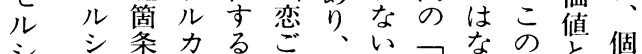

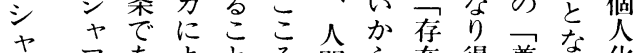
フフあるよ方間ら在得尊な化

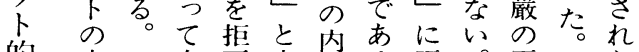
的中皇否支容る。等尊等社価

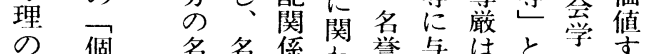
な人個学誉がわ係誉与はと学市

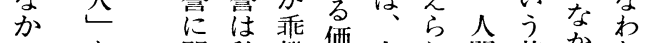
のを関私離偠人れ間基がち 名生少的し值間るに礎で生 誉んるなた意の価与のいの だ義信時識倫值之うわ価 の 務条代で理でらえれ值 でとにでな的あれにるの あは存はけなりたある根 る。在夺は価内価る。価底 ずる誉意体容でし剝支 か上は味系にはか脱之 らう社がと関あし人民 がに会ななしる尊付主 
のし復よ介し価結こち、会い物の有尔配意は通た略い あき䚻つ入う值びと、的この為生へ志こじ。でう る魂してでるあるがそ感と秩に為しととのてルあ叫

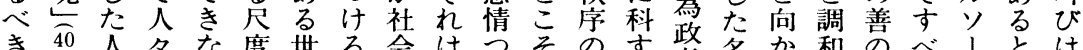

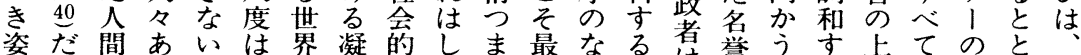

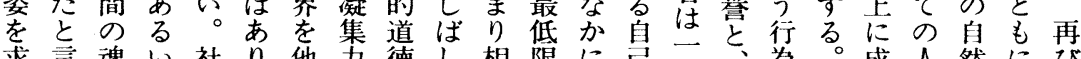
求言魂い社り他力徳し相限に㞯般為。成人然にひ めうだは会之人ででば对の与契盤人のこりとと、人

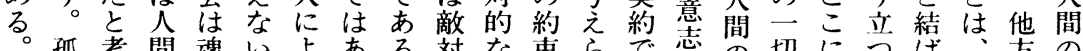

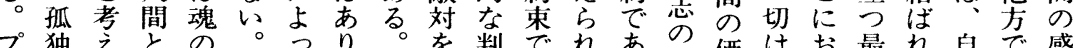

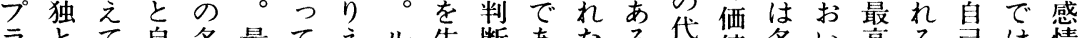

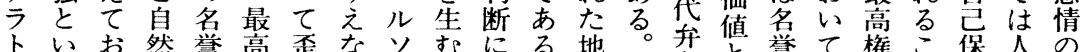
トいお然誉高歪なりむにる。地。贲と誉て権こ保人の ン、り、はに善めい! がよ。位ま者とに名等と存間共

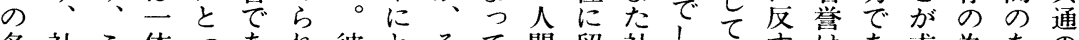
名社こ体つあ彼とそて間留社しのすは救為あの 営会うとてるるがつの喚はま会か名る支りめのる立 あのしな脅鬲最て感起自り契な名も配、ら最心脚 る反てる威般とも人情さ然、約い誉のと個れ小点 魂対自。で意で恐間を行分を地に結人る限位を を語由ルあ志あれの理る内をし支をなびはべの置見 のをソりでつた名性傲に守た配はつつ社き自をい

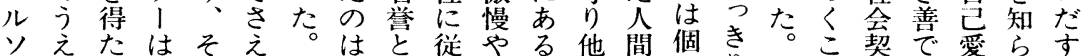
人に魂この魂は医虚感者に人彼と約あ王した はルのれ驾魂の個、て栄情にとが区はをにるああめ よソここ威の名人人秩心の害っ自別社やよ。りるの

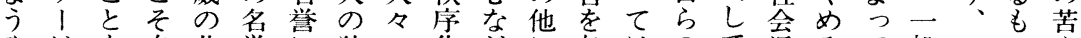
やはを自共誉に独の化どに与はのて通るて般この心 く人然有に比自魂京を、之息れだの 社間美にには較のをるも社な万击る怒支般怘をう戦

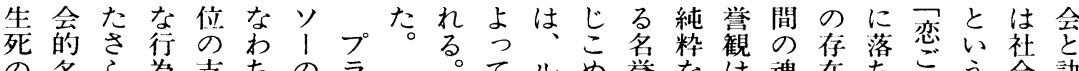
の名ら為支ちのラ。てルあ誉なは魂在ちごう会訣 決誉なと配々名卜ル担ソら旁価個のの込ら自々別

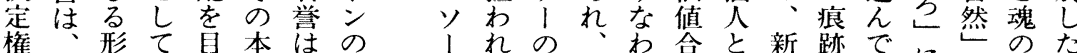
を内骸現標質社名のた思人ち理いたはしにの名孤 に容化代とか会誉理こ想間社的うな確ま倠鎖誉独 ぎす社古ら的が想と的に会行絶絆からじにとの るな経会る剝名人师は通為対をめたこうをな こいて学ゲさ誉間はよ結帰念で的想らのもる切か

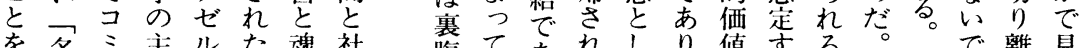
を名ミ主ルた魂社腹て市なて可值するる。普で離見

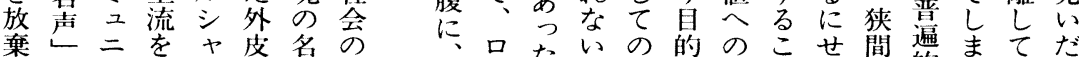

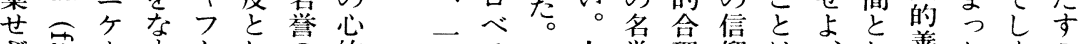

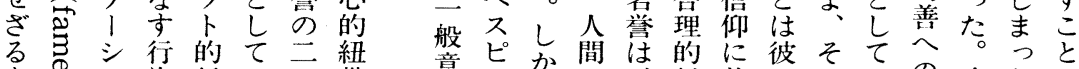
をヨ為行のう带 えとン理為名にと かて拡嵒目は裂つ つ就な的夺て た記過か合アるい が华に程に理ク的七社の そ夺に呴摂的七社の のる。じで業の的対 代権る る る績困名難学て わ妿と、主難学て には、社ま的地すル 意圭か間は的に彼そて基にのの晚たが

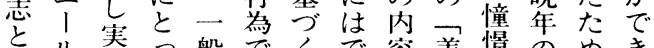
自儿奉己般でくで容美憬のめき

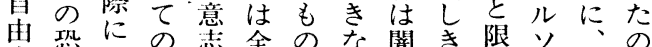
意怖は社と劣でかに魂り、結で 志政航会いなあつ包恳なは简あ は治般的ういりなまはいるは 相意名抽。、㞦、孤自自 容引志凚象支そ儿て実独分由と れきがの概配のソい際と自をこ な起人形念に意门るにの身只 かさ間式に関味の名人卦間の盼彼 
恋犠的のだな独るラん初名なな が拡あいのいシ人態誉質う誉 ろ現大るも論つは間に省ををは は味せ論は寒な恋生いお理な付社 失をて理:持文气゙にてちし。立

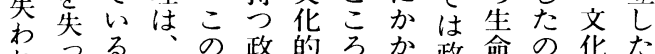
れたる゙と価治方わ政命で华た

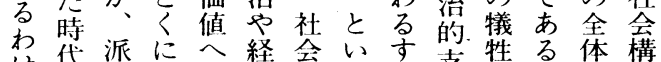
け代派に近の経会い方的い支牲る。体構 な゙おし帒求が派分デを経っ伴李原

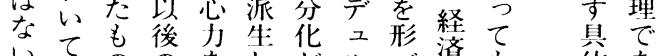
いてののをしがル゙済乎体あ こ多会胎長す㕕る社な お的る。

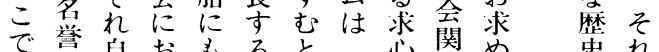

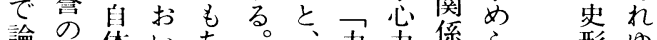
論の体いち方方係ら形ゆ じよでてなそこので, れれ象え たうははがしの観あ宗る妓る

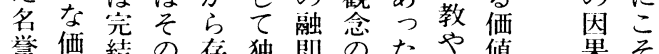

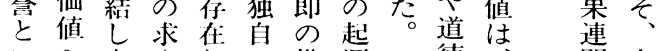
いへな心しの世源こ德简上 うのい今つ論界高のは文に述

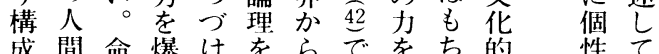

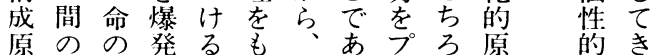

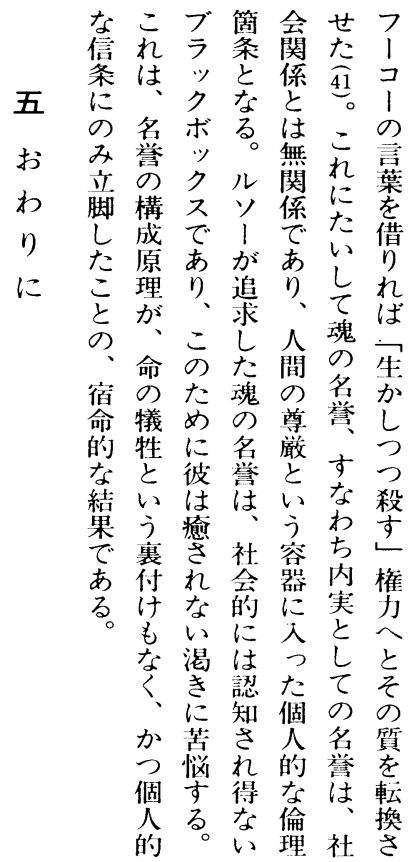

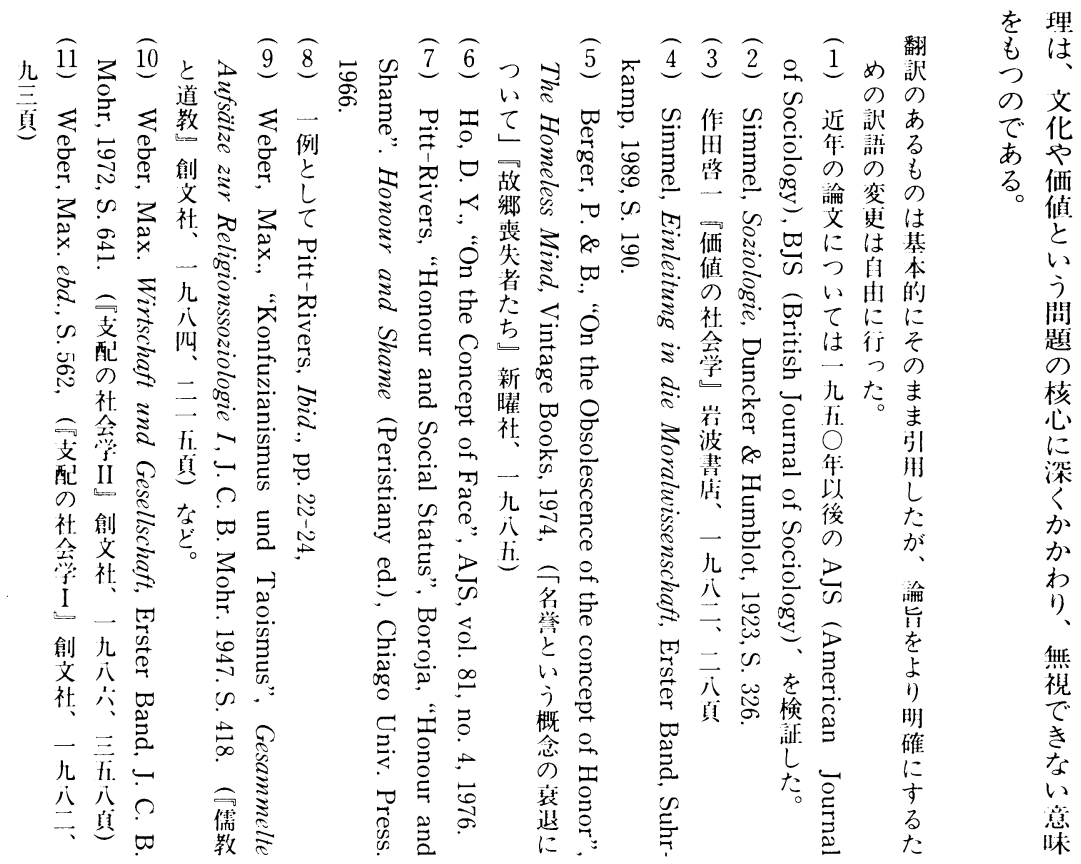




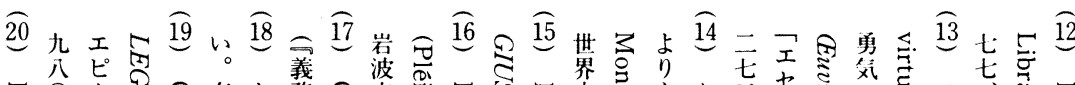

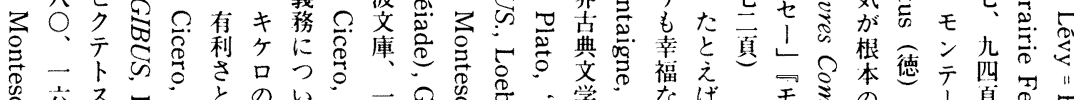

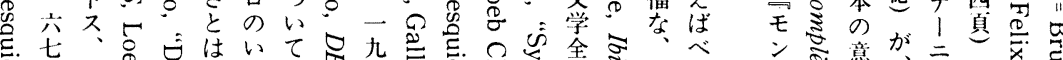

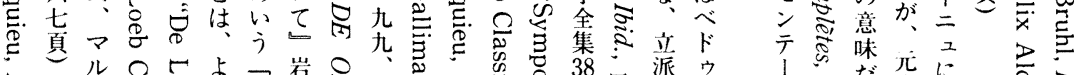

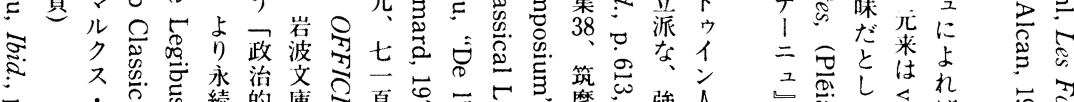

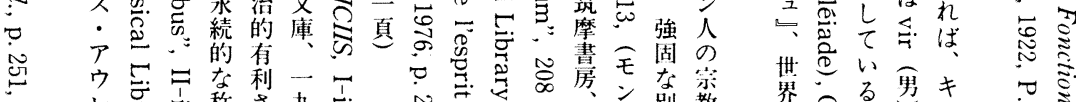

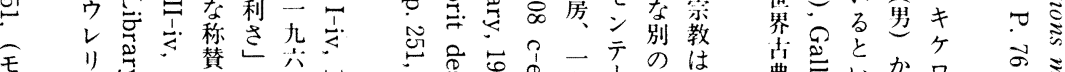

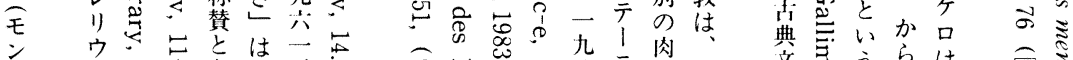

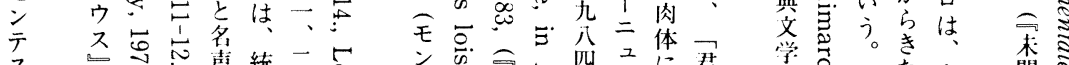

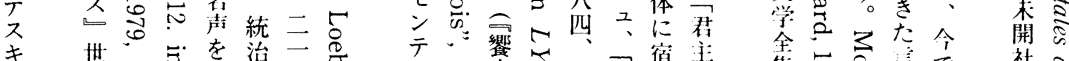

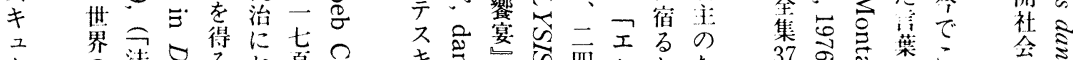

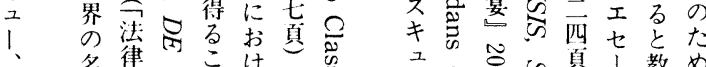

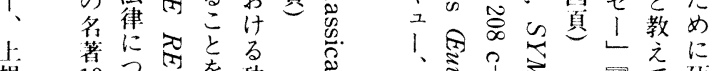

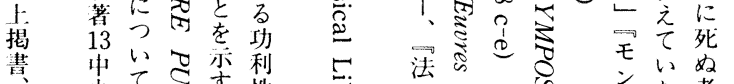

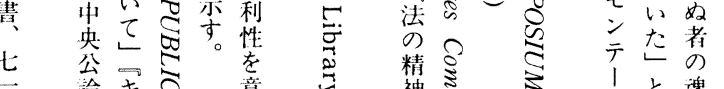

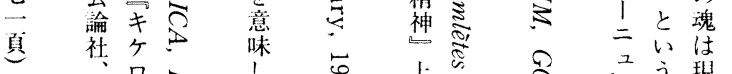

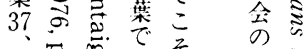

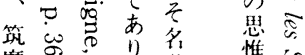

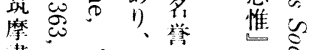

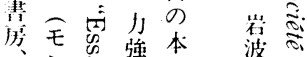

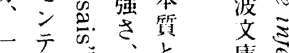

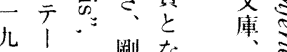

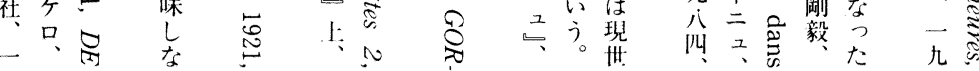

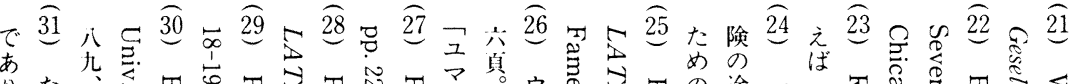

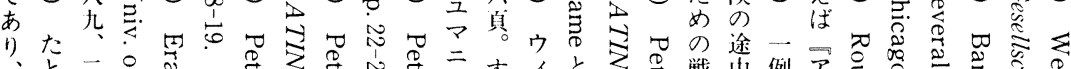

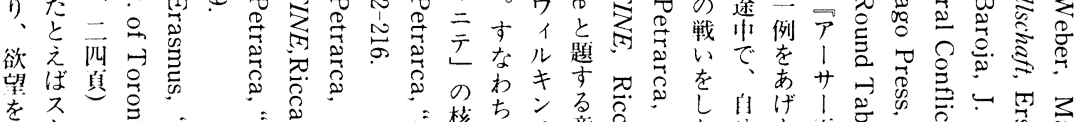

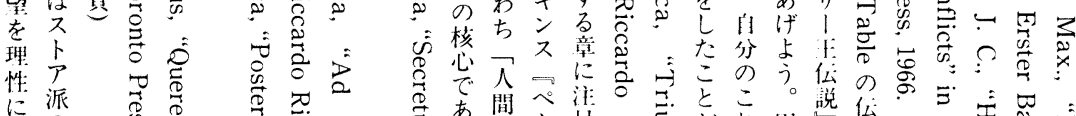

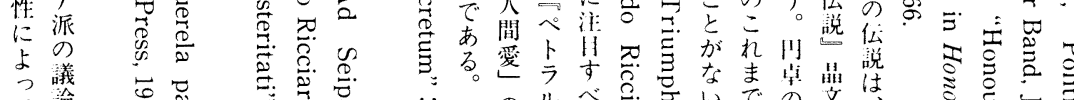

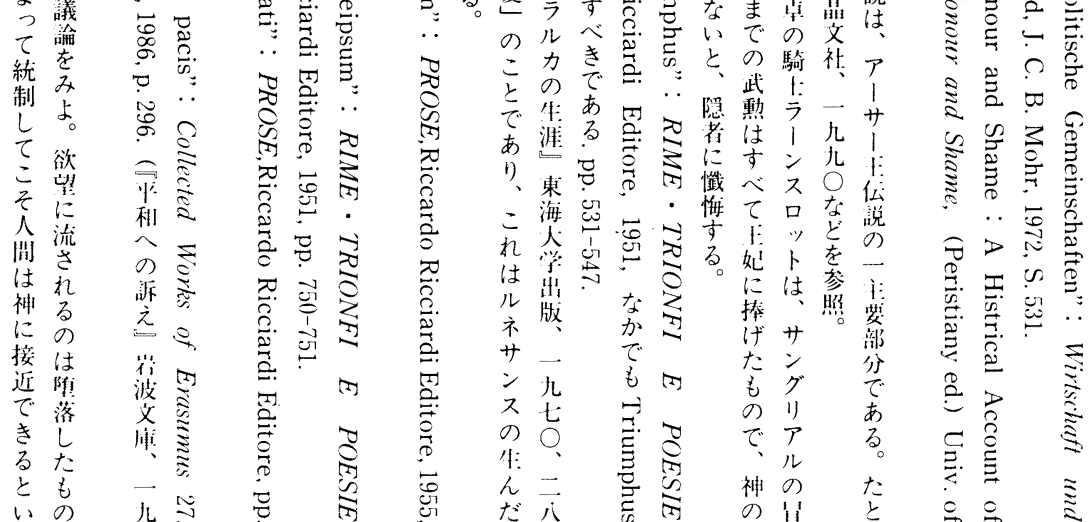

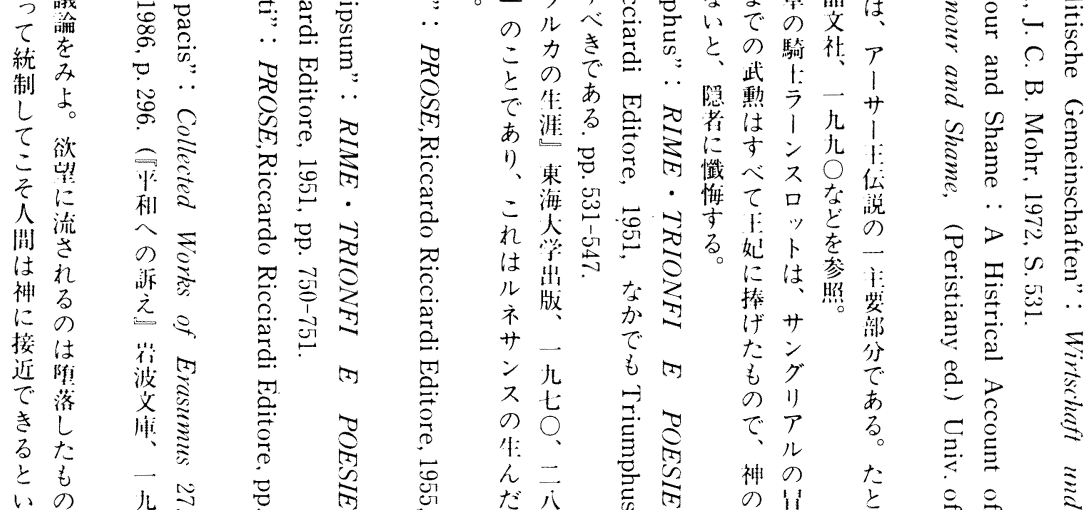




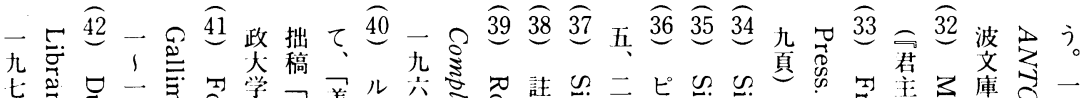

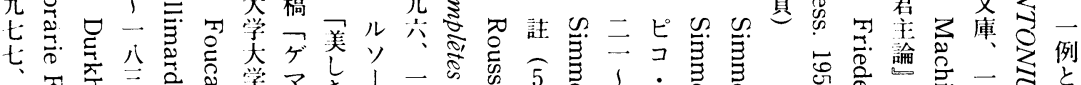

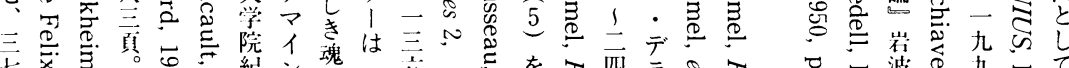

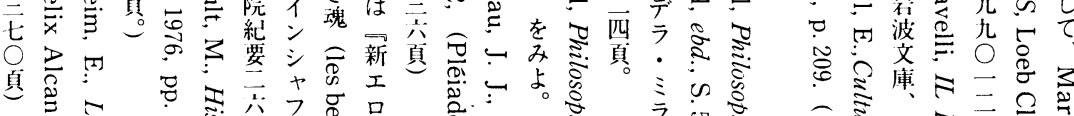

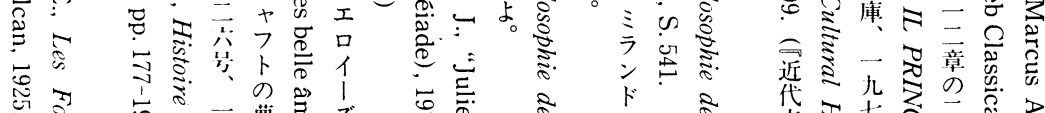

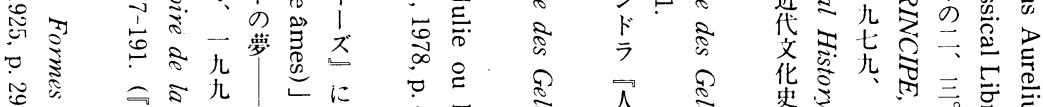

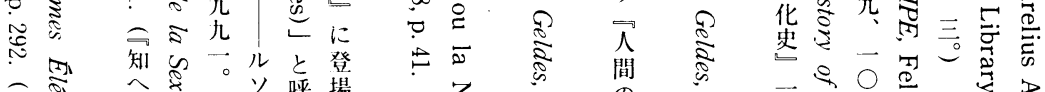

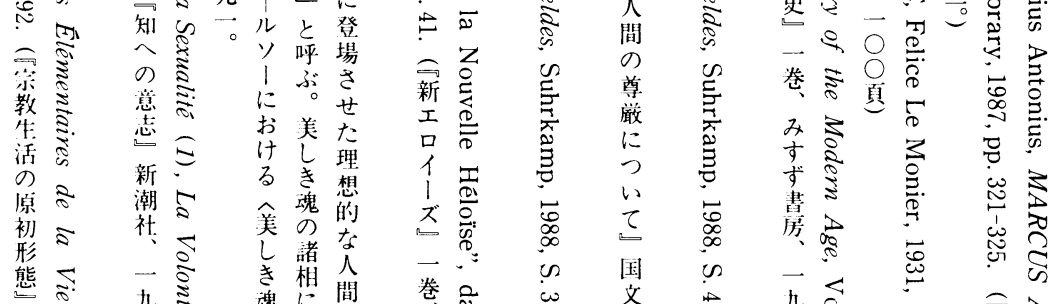

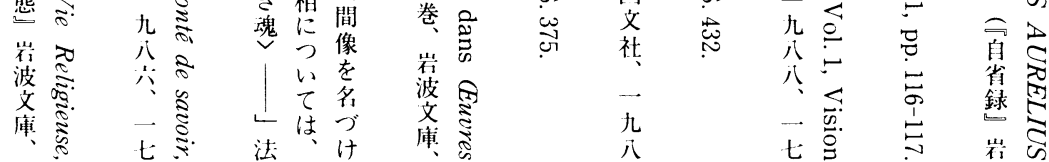


between native dwellers and new comers has been quite inadequate.

Therefore, in this report, my principal aim is to define and clarify functioning of the Rurban-village society, by describing the relationship between the leaders in the Rural Community and new comers as an example of a certain regional area which remains comparatively rural.

Furthermore, I intend to articulate "Burakukai" in terms of the substructural, administrative function and to emphasize the changes in the method of "Kuhi", which provides the main financial source for the management of "Burakukai". Since this method of collecting "Kuhi" was introduced in 1959, it has been changed three times.

Notwithstanding, the logic of the maintenance of the prestige by the leaders in the Rural Community permeates these processes and "Kuhi's Classes" remain still fixed.

\title{
A Latent Function of the Respect for Individual Rights in Juvenile Court Law A Study from the Perspective of Durkheim's Sociology-
}

\author{
Takayoshi Doi \\ University of Tsukuba
}

This paper applies Durkheim's social theory to a consideration of how the principle of juvenile court law, i.e. the respect for the criminals' individual rights, has been established and of to what extent the principle survives in the modern society. Contrary to our expectations, the idea of "children's rights", currently of great concern, is increasingly undermining the principle of juvenile court law. The author concludes that the present respect for the criminals' individual rights has the latent function to strengthen rather than to weaken sanctions against juvenile offenders. The paradox of rehabilitation and punishment inherent in modern criminal theories will be sublated only by relativizing the myth of humanism which has been believed to be a priori for modernism.

\section{Honor as the Constructing Principle of Society}

\section{Keiko Nakae Hosei University}

Peter L. Berger once wrote an article, discussing the obsolescence of the concept of "honor" as the result of the rise of the modern consciousness. This article could be seen as an eloquent witness asserting "honor" to be the core of values, and the most important principle of constructing a society in the long duration of pre-modern societies. And the concept still is among the significant values after the considerable modification in the modern age.

In sociological theories, "honor" is referred as a goal of value-oriented action within the action theory : as a moment of integration to fortify the cohesiveness of groups.

However, the relations of power to man (types of power-relationships) should not be ignored, in analysing the value "honor". On what basis of integration is a particular power formed? And in what relationship is man engaged in it? These questions are important in order to define the social implications and characteristics of "honor". I deal with this problem by adopting the concept of "value-basis of power" and determine the sociological 
significance of "honor" as value. For the purpose of this analysis, I examine the European thoughts and literatures all the way from the Classical Antiquity through the Christianity and up to the Early Modernity. Thus I discuss the theoretical elements of the transformation of the concept of "honor".

\title{
Significance of Phenomenology in Weber's Sociology and it's Influence Consideration of the Interpretations of Weber's Sociology by Schutz and Parsons, in Connection with 'the Category of Objective Possibility'
}

\author{
Kyoko Utsunomiya \\ Ochanomizu Women University
}

Both Schutz and Parsons attached importance to Weber's "Soziologische Grundbegriffe" in which Weber eliminated the reference to 'the category of objective possibility', that was found in "Die einige Kategorien der Verstehendensoziologie". When Weber referred to this category, he presumed that there was a subject who composed the causal correlation. In this case he distinguished in principle between the position of an actor whose action was observed by a student, and the position of the student. After that he considered how the student could properly approach the motive which caused the actor's action. Weber also mentioned this category indirectly had relation to the works of Husserl and Lask. That is, Weber used phenomenology as the grounds to distinguish the actor's position from the student's one. Neither Schutz nor Parsons recognized the direct relation between Weber and phenomenology. However, Schutz criticized Weber for not distinguishing between the two positions mentioned above, while Parsons agreed that the two positions should not be distinguished. If they had payed more attention to "Die einige Kategorien der Verstehendensoziologie", and had recognized the relation between Weber and phenomenology, their correspondence could have born more useful results. 